\title{
Nutritional aspects of Haemorrhagic Syndrome ('Hitra Disease') in farmed Atlantic salmon Salmo salar
}

\author{
Trygve T. Poppe, Tore Håstein, Arne Frøslie, Nils Koppang \& Gunnar Norheim
}

National Veterinary Institute, P. O. Box 8156, Dep., N-0033 Oslo 1, Norway

\begin{abstract}
Haemorrhagic Syndrome (HS) or 'Hitra Disease' currently constitutes the most important disease problem in Norwegian salmonid farming. Histopathological and chemical findings strongly support the hypothesis of HS being a multifactorial disease complex in which nutritional and/or metabolic disorders are important components. The resemblance to vitamin E/selenium deficiency syndromes in other domesticated animals is discussed.
\end{abstract}

\section{INTRODUCTION}

Since 1977, Haemorrhagic Syndrome (HS) or 'Hitra Disease' has been the most important and widespread disease in farmed Atlantic salmon Salmo salar L. in Norway (Poppe et al. 1985b).

HS has been considered to be a disease complex characterized by high winter mortality, anaemia and haemorrhages (Egidius et al. 1981, 1984, Poppe et al. 1985a). So far, this disease has only been reported to occur in Norway, although an outbreak of a disease tentatively defined as 'Cold water vibriosis', but very similar to HS, has recently been reported from the Shetland Islands (Bruno et al. 1985).

It has been suggested that HS arises because of a basic disorder of non-infectious origin (Fjølstad \& Heyeraas 1985, Poppe et al. 1985b). In order to acquire a broader basis for a nutritional theory, histological and chemical investigations were carried out in different groups of salmon. In this paper the results of histological and chemical investigations in farmed (healthy and diseased) and wild salmon are reported.

\section{MATERIALS AND METHODS}

Histological examinations. Materials examined originated from 80 farmed Atlantic salmon from 20 different sea-water fish farms along the Norwegian coast. Wild salmon $(n=10)$ were caught in bag-nets off the Trøndelag coast.
Samples were collected from moribund, diseased, and apparently healthy fish at different seasons during the period 1982 to 1985 . The majority of the farmed fish were juveniles, 0.5 to $2.0 \mathrm{~kg}$, and had been in seawater cages for 5 to $12 \mathrm{mo}$. The wild fish were from 3 to $6 \mathrm{~kg}$ and had spent 1 уг in the sea. Shortly after the fish had been killed by a light blow to the head, bled and autopsied, samples of brain, gills, pseudobranch, heart, liver, spleen, head, kidney, stomach with pyloric caecae and pancreatic tissue, anterior and posterior gut, skeletal musculature and skin, were taken and fixed in $10 \%$ neutral, buffered formalin.

The samples were prepared according to standardized histological techniques and stained with haematoxylin \& eosin (HE). Some selected samples were also stained with Martius scarlet blue (MSB), Giemsa, and elastin/van Giesson (EVG). Unstained liver sections were studied by fluorescent microscopy using a Zeiss standard fluorescent microscope (excitation 350 to $410 \mathrm{~nm}$, emission $445 \mathrm{~nm}$ ) according to Roald et al. (1981).

Chemical analyses. Liver samples were collected from farmed and wild Atlantic salmon during the period 1984-1985. Farmed salmon material $(n=666)$ was taken from fish forwarded to the National Veterinary Institute for health control or disease investigation. Wild salmon $(n=54)$ were caught in bag-nets off the Trøndelag coast in Mid-Norway, in traps in a river in the Oslo area, and on long-lines in the fishing grounds around the Faroe Islands.

Samples were stored at $-20^{\circ} \mathrm{C}$ until all analyses 
were performed. The liver samples were analysed for copper ( $\mathrm{Cu})$, zinc $(\mathrm{Zn})$, iron (Fe) and selenium (Se). Selected samples (see 'Results') were analysed for mercury $(\mathrm{Hg})$ and cadmium $(\mathrm{Cd})$. All samples were digested in a mixture of nitric and perchloric acid. $\mathrm{Cu}$, $\mathrm{Zn}$, Fe and $\mathrm{Cd}$ were determined by flame atomic absorption spectrometry, $\mathrm{Hg}$ by the cold vapour technique (Haugen et al. 1985), and Se by a fluorimetric method (Ihnat 1974, Norheim \& Nymoen 1981), or a hydride generator method (Norheim \& Haugen 1985). Results are expressed as $\mu \mathrm{g} \mathrm{g}^{-1}$ wet weight. Statistical analyses were carried out according to Nissen (1982).

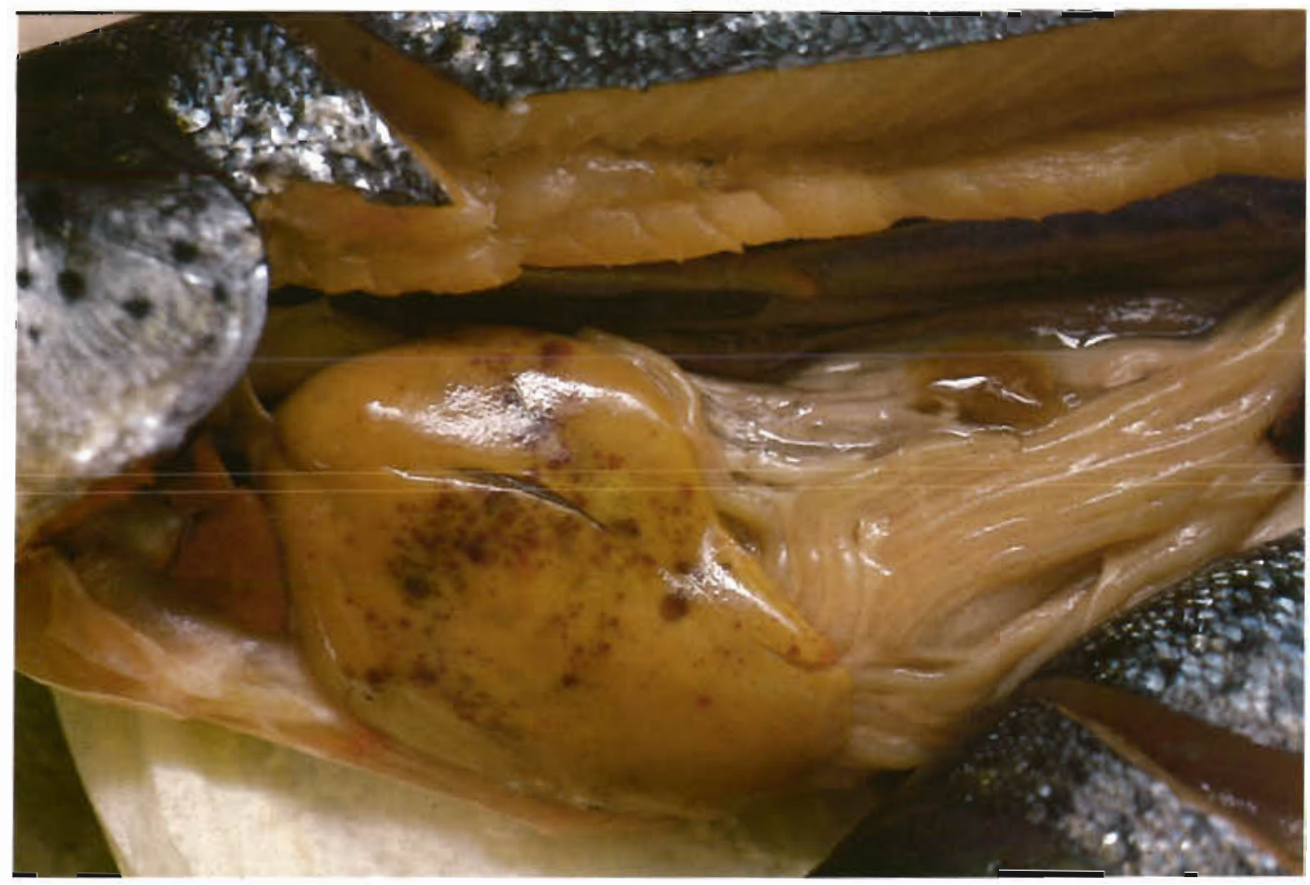

Fig. 1. Salmo salar. Macroscopical appearance of farmed salmon with HS. Note pale organs and multiple haemorrhages in the liver

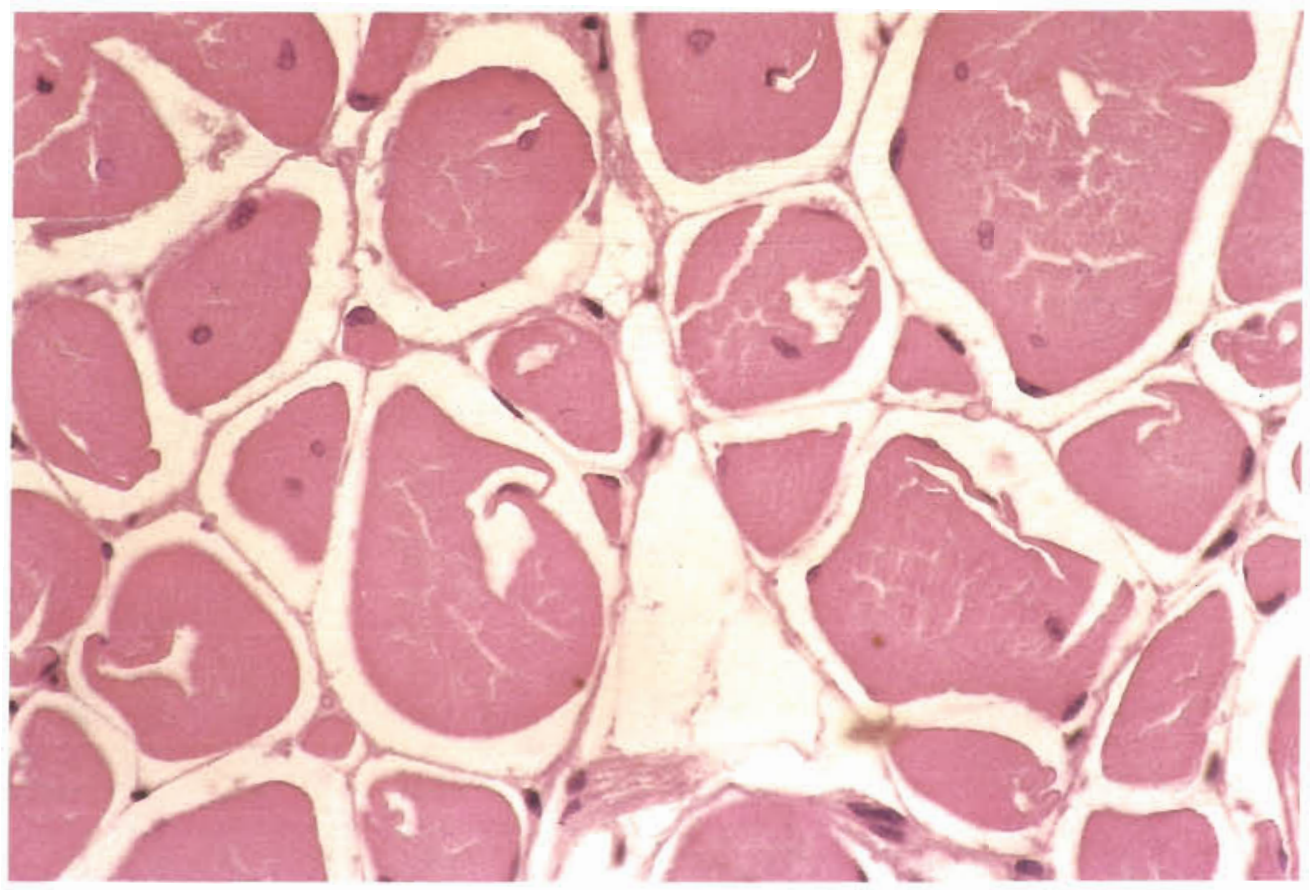

Fig. 2. Salmo salar. Body musculature of salmon with HS. Transverse section, HE, 400x. Oedema is seen between the fibrils and there is central migration of sarcolemnal nuclei 


\section{RESULTS}

About $75 \%$ of the farmed salmon matenal was characterized as 'diseased'. Similar pathological changes were seen in all the diseased fish examined. and no differences were observed between different size-classes or stocks.

Diseased farmed salmon were macroscopically characterized by abdominal reddening and haemorrhages, especially at the base of the fins and vent area. Most internal organs (gills, heart, liver, spleen) were pale and the abdominal and pencardial cavity was filled with moderate to large amounts of serohaemorrhagic fluid. Petecchiae on the pentoneum, swim bladder and perivisceral fat tissue were found in most cases, while subcapsular petecchiae in the liver were also occasionally present (Fig. 1). The kidney appeared swollen in most cases. The stomach was usually filled with mucoid fluid. A catarrhal, or sometimes haemorrhagic enteritis was common. These results are in accordance with those described in earlier studies on HS (Egidius et al. 1981, 1984, Poppe et al. 1983, 1985b).

The pathological changes described above were not present in healthy fish and wild salmon. However, a moderate hyperaemia in the vent area could be seen in some cases in healthy farmed fish, as well as petecchiae on the anterior part of the pentoneum. The liver was pale or mottled in some farmed salmon which were otherwise apparently healthy. In wild salmon fatty infiltration of the liver was occasionally seen.
The most severe histopathological changes in diseased fish were found in the skeletal and heart musculature. In other organs congestion and oedema were frequently found, as well as focal haemorrhages in some cases. Moderate hepatocellular fatty infiltration and focal liver degeneration were typical findıngs. Congestion and subcapsular (superficial) haemorrhages were also frequently found, although the liver tissue was otherwise without visible pathological changes. No ceroid-lıke materıal was observed.

Severe signs of circulatory failure with congestion, peritubular oedema and degeneration could be found in the kudney as well as haemorrhages in the haematopoietic tissue. Focal haemorrhages and clusters of bacteria were frequently found in the spleen. Congestion, oedema, focal haemorrhages and bacteria were frequently seen in the subcutaneous connective tissue. Similar changes together with desquamation of the epithelium were found in the digestive tract.

In the skeletal musculature the most characteristic feature was a mottled appearance together with a jumbled muxture of normal and dystrophic muscle $\mathrm{f}_{1}$ brils. The intermuscular spaces were wider than normal and often filled with a protemaceous fluid. Although the sarcolemnal membrane was intact, the contents showed varying degrees of degeneration (Fig. 2). Most typical was diffuse swelling and loss of striations and homogenzation of the muscular tissue. The most severe lesions were located close to the intermyotomal fascial tissue. Central migration of sarcolemnal

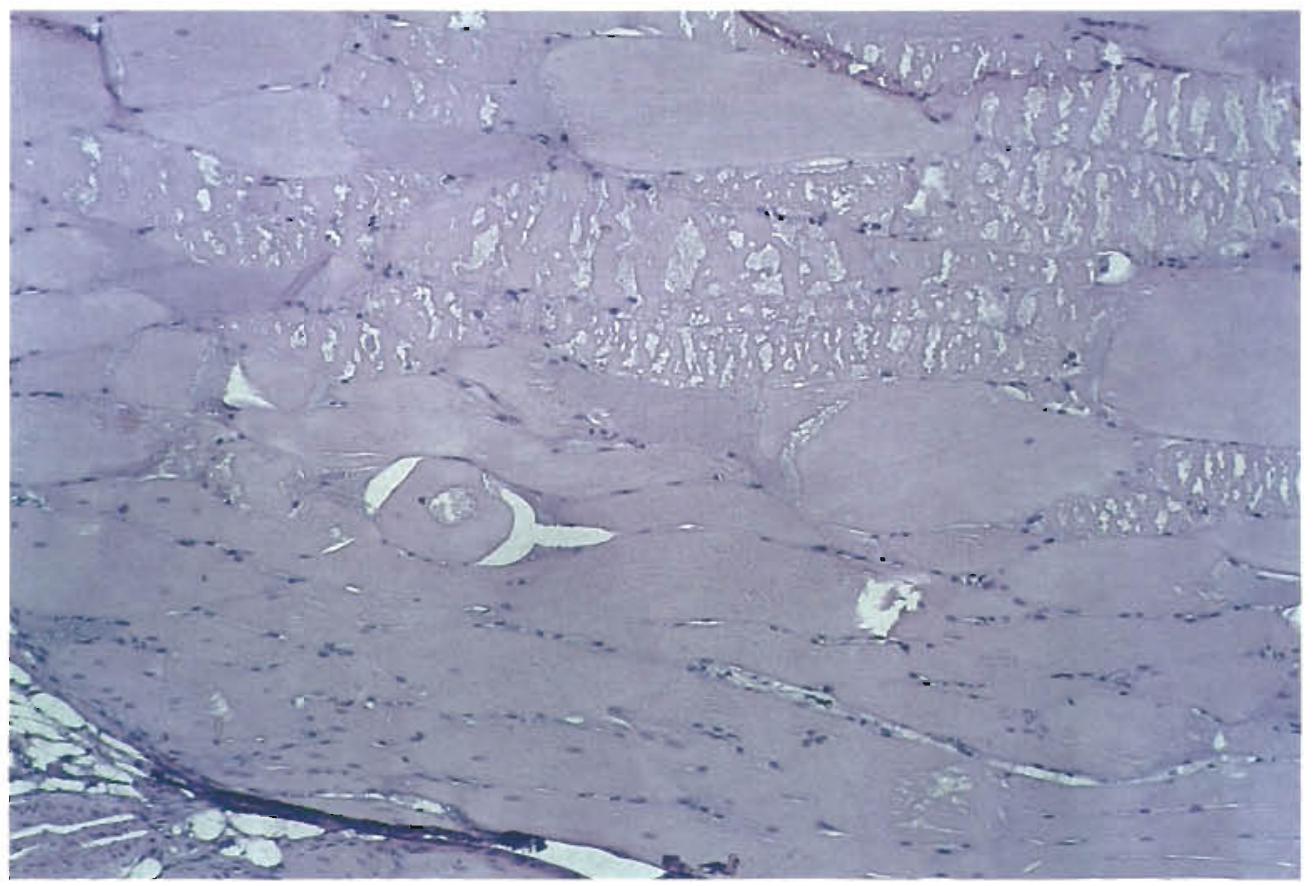

Fig. 3. Salmo salar. Body musculature of salmon with HS. Longitudinal section, HE, 100×. Note severe muscular degeneration and exudative diathesis 


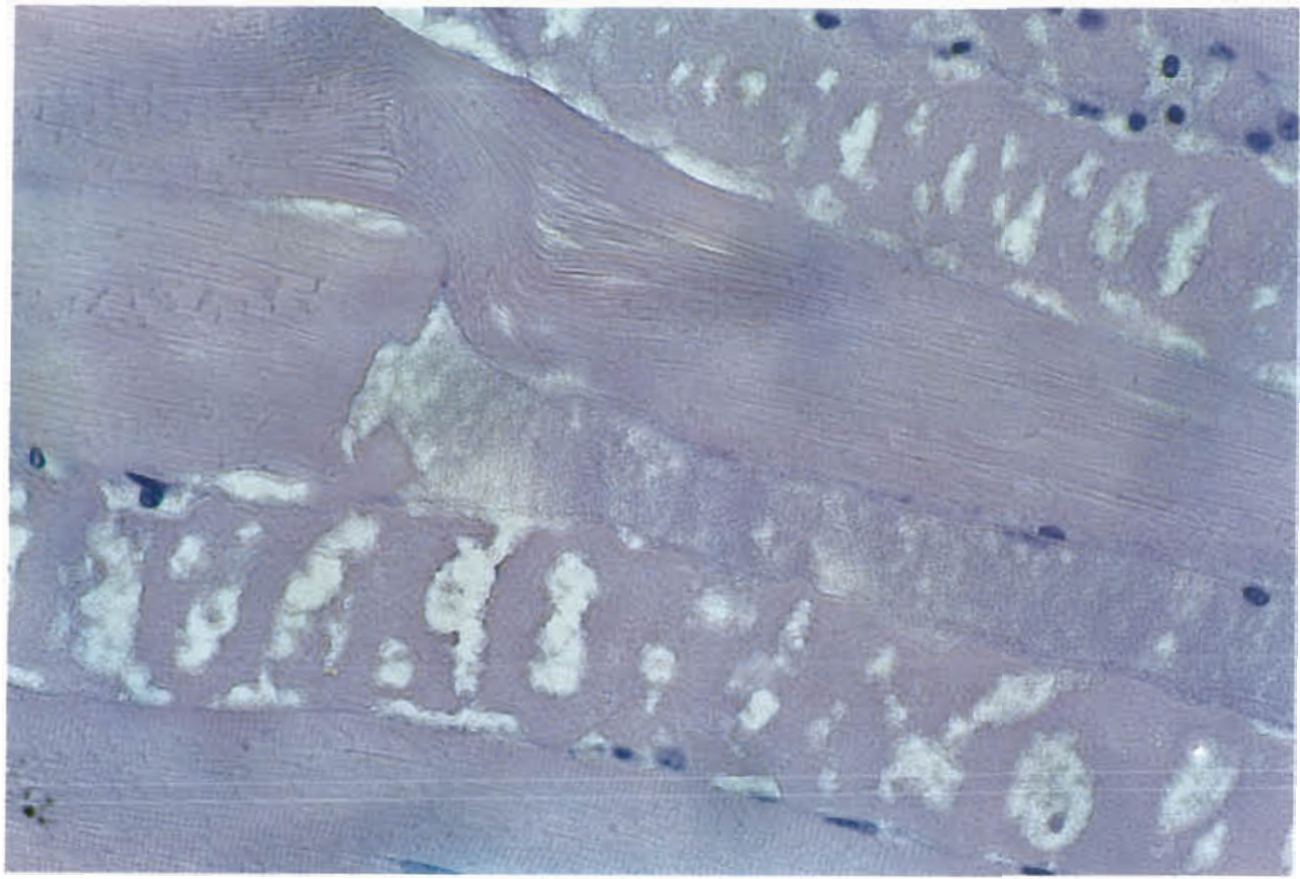

Fig. 4. Salmo salar. Detall from Fig. 3. HE, 400x

nuclei was found in some cross sections. 'Piling' of sarcolemnal nuclel could be seen in some cases, probably indicative of regenerative processes. The muscular lesions described above could also be observed in farmed fish otherwise charactenzed as 'healthy', especlally in winter.

In fish charactenzed as obviously diseased, 1.e. in later or advanced stages of the disease, the lesions were of the same type as those already described, though more pronounced. Exudation was more evident with discoid and/or granular degeneration (Fig. 3 \& 4). Haemorrhages could occasionally be seen near the intermuscular septae. Bacteria could be seen as clusters or single cells in the degenerated muscle fibres and in the exudates, especially in Giemsa stained preparations. Vacuolation of the degenerated musculature was frequently seen.

In the myocardium longitudinal and cross-striations were usually diffuse or absent. In the borderline between furm and spongy musculature, small focal haemorrhages and clusters of bacteria could frequently be seen, especially in advanced stages of the disease. The epicardium was infiltrated with mononuclear cells and was moderately to severely thickened. No pathological changes were observed in the heart or skeletal musculature of wild salmon.

The results of the analyses for $\mathrm{Cu}, \mathrm{Zn}$, Se and Fe are summarized in Table 1. Selenium levels were on aver-

Table 1. Salmo salar. Mean concentratıons and ranges of copper, zınc, ron and selenıum ( $\mu \mathrm{g}^{-1}$ wet weight) in liver from wild salmon and 3 groups of farmed salmon $n$ : number of samples

\begin{tabular}{|c|c|c|c|c|c|c|c|c|}
\hline \multirow[t]{2}{*}{ Group } & \multicolumn{2}{|c|}{ Copper } & \multicolumn{2}{|r|}{ Zinc } & \multicolumn{2}{|r|}{ Iron } & \multicolumn{2}{|c|}{ Selenium } \\
\hline & $\mathrm{n}$ & $\mu \mathrm{g} \mathrm{Cu} \mathrm{g}{ }^{-1}$ & $\mathrm{n}$ & $\mu g \mathrm{Zn} \mathrm{g}^{-1}$ & $\mathrm{n}$ & $\mu \mathrm{gFe} \mathrm{g}^{-1}$ & n & $\mu \mathrm{g} \mathrm{Se} g^{-1}$ \\
\hline Wild saimon & 37 & $\begin{array}{l}184 \pm 78^{1} \\
(29-390)\end{array}$ & 37 & $\begin{array}{l}31 \pm 5^{1} \\
(1940)\end{array}$ & 37 & $\begin{array}{l}148 \pm 89^{1} \\
(48-440)\end{array}$ & 54 & $\begin{array}{c}14 \pm 6.3^{1} \\
(2.4-35)\end{array}$ \\
\hline Healthy farmed salmon & 233 & $\begin{array}{l}75 \pm 45^{2} \\
(9-230)\end{array}$ & 233 & $\begin{array}{c}33 \pm 11^{1} \\
(14-95)\end{array}$ & 196 & $\begin{array}{l}136 \pm 89^{1} \\
(24-820)\end{array}$ & 260 & $\begin{array}{c}2.4 \pm 0.9^{2} \\
(0.6-6.0)\end{array}$ \\
\hline Farmed salmon with HS & 85 & $\begin{array}{l}41 \pm 26^{3} \\
(5-140)\end{array}$ & 85 & $\begin{array}{l}26 \pm 11^{2} \\
(12-76)\end{array}$ & 80 & $\begin{array}{l}70 \pm 45^{2} \\
(2-340)\end{array}$ & 181 & $\begin{array}{r}1.8 \pm 0.6^{3} \\
(0.8-4.7)\end{array}$ \\
\hline $\begin{array}{l}\text { Farmed salmon with diseases } \\
\text { other than HS }\end{array}$ & 225 & $\begin{array}{l}83 \pm 74^{2} \\
(5-630)\end{array}$ & 225 & $\begin{array}{r}30 \pm 9^{1} \\
(6-65)\end{array}$ & 102 & $\begin{array}{l}118 \pm 65^{1} \\
(25-320)\end{array}$ & 108 & $\begin{array}{l}2.2 \pm 1.0^{2} \\
(0.6-5.4)\end{array}$ \\
\hline
\end{tabular}


Fig. 5. Salmo salar. Correlation between hepatic levels of copper and selenium in wild ( 1$)(\mathrm{n}=36)$ and farmed salmon $(\mathrm{O})$ $(\mathrm{n}=320)$. (a): Average of 10 samples of farmed salmon. The 2 straight lines represent the range covered by $90 \%$ of samples in the 2 groups, respectively

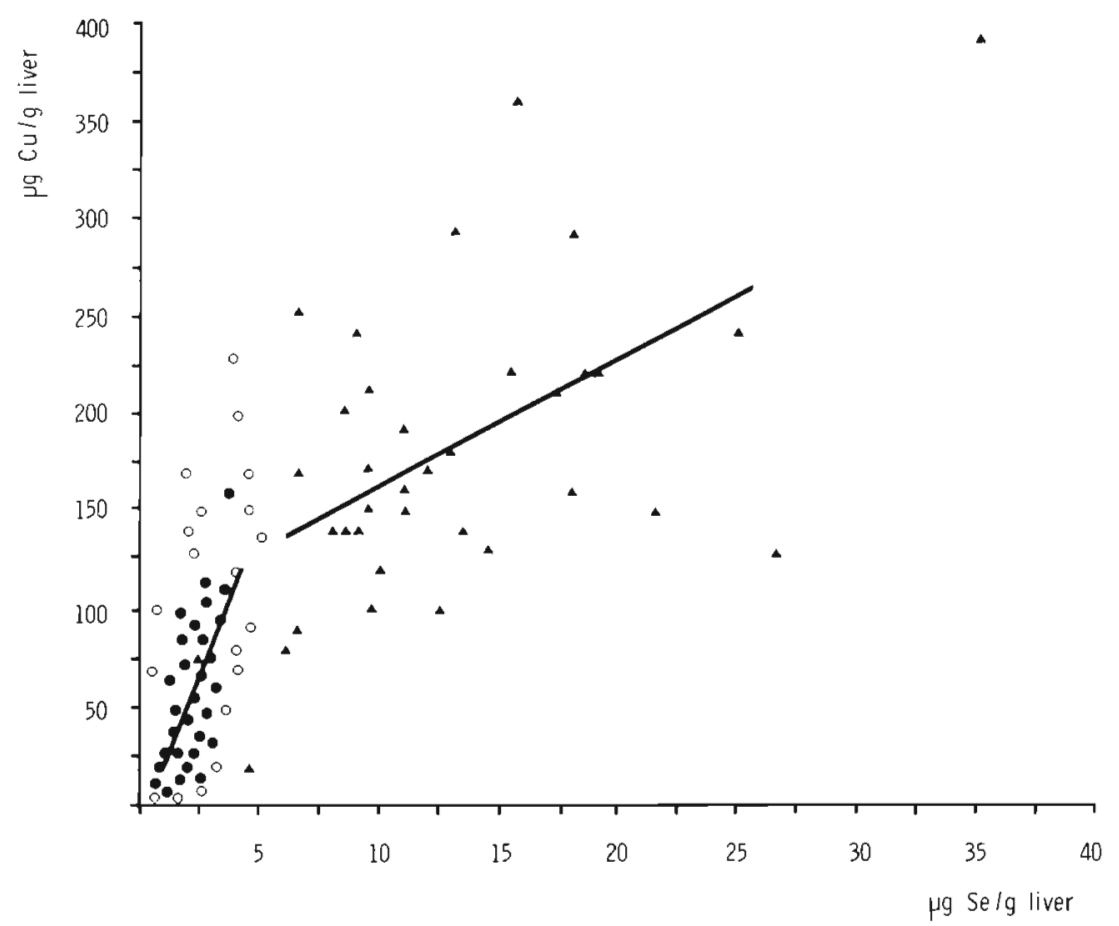

age 6 to 7 times higher in liver of wild salmon as compared to farmed salmon. Levels of $\mathrm{Cu}$ were also significantly higher in wild salmon, while those of $\mathrm{Fe}$ and $\mathrm{Zn}$ did not differ between farmed salmon as a whole, and wild salmon. Among farmed salmon, the group suffering from HS had slightly lower hepatic levels of all 4 elements than the other groups. There was a strong positive correlation $(r=0.70)$ between liver levels of $\mathrm{Cu}$ and $\mathrm{Se}$ in farmed salmon and a fairly good correlation ( $r=0.56$ ) in wild salmon. The regression coefficients, however, differed considerably, being 0.31 and 0.06 , respectively (Fig. 5). No further correlations were found between the elements. Mercury levels were almost the same in farmed and wild salmon, being on average 0.02 to $0.04 \mu \mathrm{g} \mathrm{g}^{-1}$ and 0.03 to $0.05 \mu \mathrm{g} \mathrm{g}^{-1}$, respectively. Cadmium, on the other hand, differed considerably, with levels below the detection limit of $0.1 \mu \mathrm{g} \mathrm{g}^{-1}$ in farmed salmon and 0.17 to $0.46 \mu \mathrm{g} \mathrm{g}^{-1}$ in wild salmon.

\section{DISCUSSION}

The predominant necropsy findings in $\mathrm{HS}$ are anaemia, congestion, oedema, serohaemorrhagic fluid in the body cavities and haemorrhages. The histopathological findings in this investigation were characterized by marked congestion of internal organs, exudative haemorrhagic diathesis and muscular dystrophy and degeneration. Although no macroscopic lesions were seen in the musculature, principal lesions in fish with HS were degeneration and exudative diathesis both in skeletal and cardiac musculature. Such findings have not been associated with any of the classical infectious diseases of fish, but they are well recognized in nutritional and/or metabolic diseases.

Exudative and haemorrhagic diathesis, as well as anaemia, are typical findings in HS (Poppe et al. 1983, Waagebø et al. 1985). In addition, increased activity of serum aspartate aminotransferase (ASAT) and in some cases alanine aminotransferase (ALAT) have been recorded in fish with HS (Braekkan pers. comm. 1985).

Similar changes are typical findings in selenium/ vitamin $\mathrm{E}$ deficiency syndromes in domestic animals (Blood et al. 1983). These diseases have been well documented both pathologically and aetiologically (Obel 1953, Grant 1961, Nafstad 1970, Nordstoga 1983). Typical for these diseases are congestion, oedema, exudative and haemorrhagic diathesis, anaemia, microangiopathy, muscular and myocardial dystrophy and/or degeneration ('mulberry heart disease), focal liver degeneration ('hepatosis dietetica'), steatitis ('yellow fat') and catarrhal enteritis. On the basis of findings in a series of experiments in pigs, Nafstad (1970) concluded that vitamin E deficiency is manifested by a wide variety of organ changes that are related disorders forming different parts of a syndrome. Extensive haemorrhages in the subcutaneous tissue and internal organs of rapidly growing male mink kits with vitamin $E$ /selenium deficiency have been described by Nordstoga (1983). In this case the haemorrhages dominated the picture and camouflaged 
the muscular dystrophy which also was present. The actual way in which such disorders manifest themselves is probably dependent upon a wide range of factors, such as diet, the composition and condition of fatty acids and their interaction with other nutrients, growth rate, animal species, stress and other environmental circumstances.

As regards fish, muscular degeneration, anaemia and exudative diathesis have been demonstrated in experimental selenium and vitamin $E$ deficiency in Atlantic salmon (Poston et al. 1976). Muscular degeneration has also been demonstrated in rainbow trout Salmo gairdneri Richardson (Roberts et al. 1979), and in turbot Scopthalmus maximus L., following selenium/vitamin E depletion (Pearse et al. 1984). Recently, Fjølstad \& Heycraas (1985) described muscular and myocardial degeneration in Atlantic salmon with HS.

Oxidized fats and oils or easily oxidizable polyunsaturated fatty acids are important triggers in the selenium/vitamin $\mathrm{E}$ deficiency syndrome in domestic animals (McMurray \& Rice 1982). The feed given to farmed salmon is comprised to a large extent of unsaturated fat of marine origin. Under practical conditions raw materials for feed are often stored for prolonged periods in freezers before use. This may result in considerable rancidity of the fatty fraction of the feed (Aasgaard \& Bergsronning 1985). Oxidized oils have been shown to induce increased erythrocyte fragility and anaemia in rainbow trout (Moccia et al. 1984). Oxidized oils have also induced anaemia in farmed salmon (Rørstad 1985).

The hypothesis that HS is basically a nutritional or metabolic disorder is also supported by the finding in the present study of muscular dystrophy in apparently healthy fish from farms with HS. Bacteria are seldom detected or isolated from such fish, although easily demonstrated in later stages of the disease. The slowgrowing, cold-water Vibrio spp. isolated from salmon with HS (Egidius et al. 1981, 1984, Holm 1985, Poppe et al. 1985b) may therefore be secondary invaders in a host already weakened and stressed by nutritional or metabolic disorders in addition to thermal and other physical stress factors (Snieszko 1974). Decreased immune response has been found in rainbow trout in association with vitamin E deficiency (Blazer \& Wolke 1984), while depressed antibacterial activity in salmon serum has been demonstrated by feeding rancid oils (Rørstad 1985)

The considerable difference registered between hepatic selenium levels in wild and farmed salmon is remarkable, although not unequivocally indicative of selenium deficiency in farmed fish. Critical and optimal selenium levels in fast-growing farmed salmon have not yet been ascertained. Marine fish, e.g. cape- lin Mallotus villosus, constitutes the greater part of the feed for farmed salmon. This type of raw material is considered to be a good selenium source, and one should therefore not expect the occurrence of selenium deficiency. Requirements for selenium and its availability from different sources under practical fish farming conditions are not known. Nor is it possible to interpret the difference in hepatic selenium levels in HS-diseased salmon, compared to other groups, as an indication of selenium deficiency of causal significance. The lower selenium levels, as well as the lower

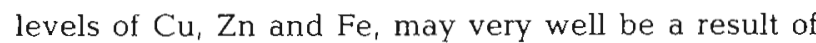
reduced feed intake, reduced transport or storage capacity or enhanced clearance. Certain heavy metals such as mercury $(\mathrm{Hg})$ may induce selenium accumulation in marine mammals (Koeman et al. 1975, Kari \& Kauranen 1978), a molar $\mathrm{Hg}$ : Se ratio close to 1 being often found. Accumulation of these 2 elements thus occurs in parallel, although the greater part of selenium is used in the detoxification of mercury. The interaction between selenium and mercury in fish seems to be more complex and is far from being completely understood (Frøslie et al. 1985). There was a fairly strong positive correlation between copper and selenium in farmed salmon in the present investigation. Such a relation between these elements in salmon has also recently been reported by Julshamn et al. (1985). The weaker correlation between Se and $\mathrm{Cu}$ in wild salmon and the different regression coefficients make it difficult to explain the higher hepatic selenium levels in wild salmon on the basis of a linear relation to copper. There may well be, however, a non-linear relation between the 2 elements when wild and farmed salmon are considered together.

The levels of other heavy metals found are probably of only minor importance in relation to the selenium levels.

Vitamin E and other antioxidants are generally added to commercial fish feeds in Norway, although no data are available regarding actual vitamin $E$ levels in fish feed which is used.

As regards serum vitamin $E$ levels in fish, data, albeit limited, indicate that levels are higher in wild salmon than in farmed salmon (Poppe et al. 1985a). The significance of this finding, the critical levels of serum vitamin $E$ in salmon and the importance of vitamin $\mathrm{E}$ per se in the etiology of $\mathrm{HS}$ are, however, difficult to evaluate. It is interesting to note that HS seldom causes any significant losses in rainbow trout raised on the same farms and fed the same diet as salmon which develop the disease (Håstein pers. comm.). This observation may indicate interspecies differences in the utilization of essential nutrients and/ or response to nutritional disorders (Moccia et al. 1984). 
Selection for rapid growth in farmed salmon has resulted in an increase in the growth rate of about $3 \%$ $\mathrm{Yr}^{-1}$ (Gjedrem pers. comm.). This genetic improvement, together with the expanded use of intensive practices in salmon farming in general and higher stocking densities in particular, probably means that the provision of a well-balanced diet is of ever-increasing significance and that requirements for essential nutrients have perhaps increased.

\section{CONCLUSION}

As a whole, the pathological changes described in this investigation are indicative of a metabolic or nutritional disorder. It is, however, not possible to pin-point a single factor or factors that induce $\mathrm{HS}$ in farmed salmon. Nevertheless, it may be suspected from the present findings that the syndrome arises because of a basic disorder of non-infectious origin, probably of nutritional or metabolic nature, and that the primary task for future research is to clarify the etiology of the syndrome so that improved prophylactic measures can be introduced.

\section{LITERATURE CITED}

Aasgaard, T., Bergsronning, J. E. (1985). Samansetjing og feitt-kvalitet i fiskefôr. (Composition and fat quality in fish feed). Norsk Fiskeoppdrett (Bull. Norw. Fish Farmers Ass.) 1: $16-17$

Blazer, V. S., Wolke, R. E. (1984). The effects of $\alpha$-tocopherol on the immune response and non-specific resistance factors of rainbow trout (Salmo gairdneri Richardson). Aquaculture 37: 1-9

Blood, D. C., Radostitis, O. M., Henderson, J. A. (1983). Veterinary medicine, 6th edn. Bailliere Tindall, London

Bruno, D. W., Hastings, T. S., Ellis, A. E., Wootten, R. (1985). Outbreak of a cold water vibriosis in Atlantic salmon in Scotland. Bull. Eur. Ass. Fish Pathol. 5: 62-63

Egidius, E., Andersen, K., Clausen. E., Raa, J. (1981). Coldwater vibriosis or 'Hitra Disease' in Norwegian salmonid farming. J. Fish Dis. 4: 353-354

Egidius, E., Soleim, Ø., Andersen, K. (1984). Further observations on cold-water vibriosis or Hitra Disease. Bull. Eur. Ass. Fish Pathol. 4: 50-51

Fjølstad, M., Heyeraas, A. L. (1985). Muscular and myocardial degeneration in cultured Atlantic salmon (Salmo salar L.) suffering from 'Hitra Disease'. J. Fish Dis. 8: 367-372

Frøslie, A., Norheim, G., Sandlund, O. T. (1985). Levels of selenium in relation to levels of mercury in fish from Mjøsa, a freshwater lake in southeastern Norway. Bull. environ. Contam. Toxicol. 34: 572-577

Grant, C. A. (1961). Morphological and aetiological studies of dietetic microangiopathy in pigs ('Mulberry Heart'). Acta vet. scand. 2: Suppl. 3

Haugen, A., Høie, R., Norheim, G. (1985). Automated hydride generator determination of selenium in biochemical material. 10th Nordic Automatic Spectroscopy and Trace Element Conference. Turku, Finland, August 6-9

Holm, K. O. (1985). Isolering og karakterisering av Vibrio- bakterier fra laks (Salmo salar L.) med Hitrasyke. (Isolation and characterization of Vibrio-bacteria from salmon (Salmo salar L.) suffering from 'Hitra Disease'). Thesis, Univ. of Tromse

Ihnat, M. (1974). Fluorimetric determination of selenium in foods. J. Ass. anal. Chem. 57: 368-372

Julshamn, K., Utne, F., Sandnes, K., Lie, Ø. (1985). Ekstra tilskudd av selen i fiskefôr - Er det nødvendig? (Is supplementation of Se to fish feed necessary?). Norsk Fiskeoppdrett (Bull. Norw. Fish Farm. Ass.) 3: 42-43

Kari, T., Kauranen, P. (1978). Mercury and selenium contents of seals from fresh and brackish waters in Finland. Bull. environ. Contam. Toxicol. 19: 273-280

Koeman, J. H., van de Ven, W. S. M., de Goeij, J. J. M., Tjioe, P. S., Haaften, J. L. (1975). Mercury and selenium in marine mammals and birds. Sci. Total Environ. 3: 279-287

McMurray, C. H., Rice, D. A. (1982). Vitamin E and selenium deficiency diseases. Irish Vet. J. 36: 57-67

Moccia, R. D., Hung, S. S. O., Slinger, S. J., Ferguson, H. W. (1984). Effect of oxidized fish oil, vitamin $E$ and ethoxyquin on the histopathology and haematology of rainbow trout, Salmo gairdneri Richardson. J. Fish Dis. 7. 269-282

Nafstad, I. (1970). Studies of experimental vitamin E-deficiency in pigs. Thesis. Universitetsforlaget, Oslo

Nissen, $\varnothing$. (1982). Statistikkprogram for CP/M-maskiner (Statistics programme for CP/M machines). Norges Landbrukshøgskole, Inst. for plantekultur, melding nr. 202 , p. $1-55$

Nordstoga, K. (1983). Muscular and myocardial degeneration in rapidly growing male mink kits. Acta vet. scand. 24: 321-324

Norheim, G., Haugen, A. (1985). Precise determination of selenium in tissues using automated wet digestion and an automated hydride generator atomic absorption spectroscopy system. Nordic Symposium on Metabolism of Trace Elements Related to Human Disease. Loen, Norway, June $10-13$

Norheim, G., Nymoen, U. K. (1981). Fluorimetric determination of selenium in biological material using automated digestion. 8th Nordic Trace Element and Microchemistry Conference. Sandefjord, Norway, June 10-13

Obel, A. L. (1953). Studies on the morphology and etiology of so-called toxic liver dystrophy (Hepatosis diaetetical in swine. Acta. path. microbiol. scand. Suppl. 94

Pearse, L., MacQueen, A., Roberts, R. J. (1984). Muscular dystrophy in cultured turbot (Scophthalmus maximus L.). Vet. Rec. 11: 435-437

Poppe, T. T., Håstein, T., Salte, R. (1983). Hemorrhagisk syndrom hos laks. En oversikt. (Haemorrhagic syndrome in salmon. A review). Norsk Veterinærtidsskrift (Bull. Norw. vet. Ass.) 95: 317-323

Poppe, T. T., Håstein, T., Frøslie, A., Norheim, G., Heum, M. (1985a). Vitamin E, selenium, copper and zinc in Atlantic salmon (Salmo salar L.): Comparative studies of wild and farmed fish. Bull. Eur. Ass. Fish Pathol. 5: 28-29

Poppe, T. T., Håstein, T., Salte, R. (1985b). Hitra Disease (Haemorrhagic syndrome) in Norwegian salmon farming. Present status. In: Ellis, A. E. (ed.). Fish and shellfish pathology. Academic Press, London, p. 223-229

Poston, H. A., Combs, G. F., Jr., Leibovitz, L. (1976). Vitamin E and selenium interrelations in the diet of Atlantic salmon (Salmo salar L.): Gross, histological and biochemical deficiency signs. J. Nutr. 106: 892-904

Roald, S. O., Armstrong, D., Landsverk, T. (1981). Histochemical, fluorescent and electron microscopical appearance of hepatocellular ceroidosis in the Atlantic salmon (Salmo salar L.). J. Fish. Dis. 4: 1-14 
Roberts, R. J., Richards, R. H., Bullock, A. M. (1979). Pansteatitis in rainbow trout (Salmo gairdneri Richardson): A clinical and histopathological study. J. Fish Dis. 2: 85-92

Rørstad, G. (1985). Harskt fett i fôr til laks (Salmo salar L.). Virkning pà vekst, sykdomssymptomer og ulike blodparametre med spesiell referanse til fiskens motstandsevne mot sykdom. (Rancid fat in feed for salmon [Salmo salar L.]. Effect on growth, disease symptoms and different blood parameters with special reference to disease resistance). Thesis. Univ. of Tromsø
Snieszko, S. F. (1974). The effects of environmental stress on outbreaks of infectious diseases of fishes. J. Fish Biol. 6 : $197-208$

Waagebø, R., Sandnes, K., Lie, Ø. (1985). 'Bjugn Prosjektet' Hematologiske undersøkelser. (The Bjugn Research Project' - Haematological investigations). Norsk Fiskeoppdrett. (Bull. Norw. Fish Farm. Ass.) 10: 34-35

Responsible Subject Editor: Dr. G. Peters; accepted for printing on June 9, 1986 